\title{
Sustainable Consumption and Production policies
}

\section{Citizen-consumers as change agents}

\section{Environmental change is not possible without} the active involvement of key actors in civil society. For SCP policies to be successful, instruments and strategies for the greening of consumption practices have to be developed in correspondence with the lifestyle concerns of citizen-consumers.

By Gert Spaargaren

$\mathbf{T}$ he recent, Al Gore initiated green wave is truly global in character and combines an apocalyptic undertone with an explicit call for action. While in the 1970s the Club of Rome asked governments to take the lead in developing a policy response, and Gro Harlem Brundtland in the 1980s invited business organizations to join the environmental game, this time civil society actor and institutions are assigned key roles in the process of bringing about environmental change.

The increased attention for civil society actors and their consumption behaviors can be explained by a number of factors. First, both the absolute and relative environmental impacts of consumption have increased steadily and are expected to grow also over the next 30 years. Second, nation-states are loosing some of their regulatory powers and have come to rely on governance-arrangements that are shared with market- and civil society

actors, resulting in more rights and responsibilities for citizenconsumers. Third, pro-active companies over the past twenty years have been busy to develop green products and services which they seek to introduce not just to dark green consumers in niche-markets but also to so called light green consumers in emerging main markets (Spaargaren/Van Koppen 2009).

The combined result of these trends is a shift taking place in the way environment and climate-change issues are approached by both governmental and non-governmental actors. The traditional focus on supply-side actors, on providers operating at the up-stream ends of production-consumption chains and networks, has become complemented with an approach targeting end-users and their representatives at the lower-ends of the chains. With this shift, the traditional focus on environmental technologies and spatial as well as infrastructural systems has been complemented with a sincere interest in the dynamics of the life-world and the everyday life rationalities that govern consumption behaviors.
Although on an abstract level almost everyone seems to welcome the consumerist turn within environmental politics, SCPpolicies at the national and the international levels are still in their infancy (Jackson 2006; OECD 2008). It will probably take another ten years to reach a scientific and political consensus on how to address sustainable consumption issues. The aim of this contribution is to identify a few key issues we think are important for developing the SCP-agenda into a full-blown transnational agenda (Spaargaren/Mol 2008).

\section{Ecological modernization of life-styles and consumption patterns}

Some confusion seems to exist about how to define sustainable consumption in the first place. Isn't this a contradictio in terminis (Princen et al. 2002)? We think ecological modernization theory (EMT) can help solve some of the definition problems (Mol/Spaargaren 2000). EMT theorists analyzed and documented the emergence of an ecological rationality as a specific and independent sub-set of criteria, indicators and principles that govern and help shape our intercourse with nature.

Both the natural and social sciences contributed to the formalization of these new environmental principles, and their increased application and use by different actors at different levels of society represent the progress being made in environmental policy, also when consumption practices are at stake.

With their theory on reflexive modernization environmental sociologists made a specific contribution to the development and use of ecological rationalities under conditions of globalizing modernity. Thus, they were moving away from the opposition between economic growth and ecological sustainability while also taking into account the growth interests of the South. The increased use of fair trade products and labeling schemes worldwide might serve as an illustration in this respect.

\section{Consumption policies}

In order for the new eco-rationalities to be seriously considered and used by citizen-consumers in the organization of their everyday lives, the predominantly technical criteria need to be translated to and embedded in the dynamics of the life-world. To make consumption practices more sustainable, they need to be addressed as consumption practices, as forms of behaviors that represent a strong social and symbolic dimension. Consumption practices are about dreaming, display, belonging, comfort, cleanliness and convenience (Shove 2003). They are 
thoroughly social, even if we study them primarily for their unsustainable ways of using energy and material flows.

\section{Social practices as key units of SCP policies}

Most studies on environmental consumption behaviors focus on the individual and his or her preferences and choices. Since all individuals have a unique lifestyle, it is very difficult to develop consumption-policies which are fine-tuned to the lifestyles of individual citizen-consumers. As a response, policy makers often prefer to organize sustainable consumption behind the backs of consumers by regulating providers.

Within sociology a methodology has been developed which moves away from the individual and social structure dichotomy by putting forward social practices as central units for analysis and policy making (Warde 2005). Social practices are the shared routines which groups of citizen-consumers reproduce in time and space. They are the patterned, site-specific clusters of agents, meanings, and technologies. The innovative theoretical claim of these structuration theories is that agents and technological structures are co-constitutive.

In the theoretical realm, the claims are by now well established (Spaargaren 2003; Shove 2003). The main challenge is how to apply this contextual approach to consumption behavior also within SCP-policies. The identification, also in the Marrakech process, of a series of environmentally relevant social practices within a limited number of consumption domains is a major first achievement in this respect. Housing, Food, Mobility, Holidays, Clothing and Personal Care are considered as the main domains of consumption, each with their own environmental profiles, performances and dynamics of change (Tukker et al. 2006).

\section{Three political roles for citizen-consumers}

In order to be effective, legitimate and lasting, SCP policies have to engage citizen-consumers with environmental change. Identifying and analyzing the different roles through which citizen-consumers can engage themselves with the greening of consumption is an important task for sociologists and political scientists in particular.

As we have argued elsewhere in more detail (Spaargaren/Mol 2008) there can be distinguished three forms of political commitment of citizen-consumers with environmental change in globalizing modernity, corresponding with different kinds of environmental authority. First, ecological citizenship refers to the role citizen-consumers can take up in the transnational political realm to articulate environmental rights and responsibilities. Second, political consumerism refers to the organized forms of political action citizen-consumers might engage with in order to contribute to the greening of globalized production-consumption chains and networks. The organized buycotts of green products might serve as an example here (Micheletti 2003). Third, lifestyle-politics refer to the moral engagements of citizen-con- sumers who in their civic and private sphere of everyday life address global, planetary issues in a direct way, bypassing the established political institutions (Spaargaren/Mol 2008).

\section{Conclusion}

SCP-scientists and -policy makers could employ three distinguished roles to analyze and organize the political commitment of citizen-consumers with the process of eco-modernizing consumption practices in delineated consumption domains. In doing so, they contribute to the empowerment of citizen-consumers while at the same time moving away from the individualist accounts of consumption behavior that dominated the SCP-field so far.

\section{References}

Jackson, T.: Challenges for Sustainable Consumption Policy. In: Jackson, T.: The Earthscan Reader in Sustainable Consumption. London 2006, S. 109129.

Micheletti, M.: Political Virtue and Shopping; Individuals, Consumerism and Collective action. New York 2003.

Mol, A.P.J. / Spaargaren, G.: Ecological Modernization Theory in debate: a review. In: Environmental Politics 9, 1/2000, S. 17-49.

OECD: Promoting Sustainable Consumption. Good Practices in OECD Countries. Paris 2008.

Princen, T. / Maniates, M. / Conca, K. (Eds.): Confronting Consumption. Cambridge 2000.

Shove, E.: Comfort, Cleanliness and Convenience: the Social Organization of Normality. Oxford 2003.

Spaargaren, G.: Sustainable Consumption: A Theoretical and Environmental Policy Perspective. In: Society and Natural Resources 16, 2003, S. 1-15

Spaargaren, G. / Mol, A.P.J.: Greening global consumption: Redefining politics and authority. In: Global Environmental Change 18, 3/2008, S. 8.

Spaargaren, G. / van Koppen, C.S.A.: Provider strategies and the greening of consumption. In: Lange, H. / Meier, L. (Eds.): Globalizing Lifestyles, Consumerism, and Environmental Concern - The Case of the New Middle Classes. Forthcoming.

Tukker, A. et al. Environmental Impact of Products (EIPRO). Analysis of the life cycle environmental impacts related to the final consumption of the EU-25. Ispra 2006.

Warde, A.: Consumption and theories of practice. In: Journal of Consumer Culture, Spring 2005.

\section{AUTHOR + CONTACT}

Dr. Gert Spaargaren holds a special chair on 'environmental policies for sustainable lifestyles and consumption patterns' at the Environmental Policy Group at Wageningen University, Netherlands.

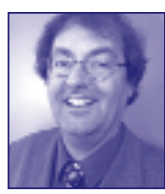
Environmental Policy Group (ENP), Wageningen University, De Leeuwenborch, Hollandseweg, 6706 KN Wageningen, Netherlands. Tel.: +31 31748 3874, E-Mail: gert.spaargaren@wur.nl, Internet: www.enp.wur.nl/uk 
(c) 20I0 Authors; licensee IÖW and oekom verlag. This is an article distributed under the terms of the Creative Commons Attribution Non-Commercial No Derivates License (http://creativecommons.org/licenses/by-nc-nd/3.o/), which permits unrestricted use, distribution, and reproduction in any medium, provided the original work is properly cited. 